\title{
Firm-level environmentally sensitive productivity and innovation in China
}

\author{
Hidemichi Fujiii, Jing Cao ${ }^{2}$, Shunsuke Managi ${ }^{3,4}$ \\ ${ }^{1}$ Graduate School of Fisheries and Environmental Sciences, Nagasaki University, 1-14 Bunkyo- \\ machi, Nagasaki 852-8521, Japan \\ ${ }^{2}$ Tsinghua University, 128 Shunde Building, Beijing, China \\ ${ }^{3}$ Urban Institute, Department of Urban and Environmental Engineering, School of Engineering, \\ Kyushu University, 744 Motooka, Nishiku, Fukuoka, 819-0395, Japan \\ ${ }^{4}$ QUT Business School, Queensland University of Technology, Level 8, Z Block, Gardens Point, 2 \\ George St, Brisbane QLD 4000, Australia
}

Phone/Fax: +81-92-802-3429, E-mail: managi.s@gmail.com

* Corresponding Author

\begin{abstract}
This study analyzes productive efficiency in relation to $\mathrm{CO}_{2}$ emissions using a unique dataset of 562 Chinese manufacturing firms for the period from 2005 to 2009 . We develop a directional distance function approach to identify technical innovators in the area of $\mathrm{CO}_{2}$ emissions. The results indicate that a large number of technical innovators are observed in the textile, paper, steel, and computer industries. Furthermore, there are clearly different trends in productivity change and corporate performance across industries and provinces. This result implies that policy makers need to consider industrial and regional characteristics to develop effective policies that conserve energy and reduce $\mathrm{CO}_{2}$ emissions.
\end{abstract}

Keywords: Technical innovator, total factor productivity, technology adoption, $\mathrm{CO}_{2}$ emissions, Chinese manufacturing firm 


\section{Introduction}

In light of the increasing concern about China's severe air pollution and energy security, the Chinese government has initiated a series of binding policy targets to address these challenges [1]. One of the government's most prominent successes was the eleventh Five Year Plan, which not only achieved an annual GDP growth of $11.2 \%$ but also improved energy efficiency by $19.1 \%$ from 2005 to 2010; the original targets had been $7.5 \%$ GDP growth and a $20 \%$ energy efficiency improvement. There was a rebound in energy use and carbon emissions during the later period of the eleventh Five Year Plan that was attributable to the stimulus package developed in response to the global economic crisis, but the overall effects, particularly the rapid energy intensity decline that occurred between 2006 and 2009, were significant. Given the new challenges related to China's intended nationally determined contribution (INDC) carbon-reduction target, understanding how China dramatically reversed-i.e., effectively curbed - its stable or potentially increasing trend in energy usage during the eleventh Five Year Plan is crucial for designing and implementing successful energy and climate policies. Our paper focuses on environmentally sensitive productivity and technical innovators and provides an ex post firm-level analysis that should help in designing more effective climate policies to achieve the INDC target for the post-2020 era.

The success of China's $11^{\text {th }}$ Five Year Plan in energy savings and pollution reduction is primarily attributable to the energy-saving activities of the non-electricity manufacturing sector in China, whose share of energy consumption was approximately $28 \%$ in 2009 . Figure 1 shows the trends in energy consumption related to value added (VA) and carbon dioxide $\left(\mathrm{CO}_{2}\right)$ emissions from 1995 to 2009. Energy consumption related to VA decreased from 1995 to 2000 primarily because of the modernization of production equipment in the industrial sector [2]. Although both of these levels increased from 2000 to 2005, they decreased again after 2005. Additionally, $\mathrm{CO}_{2}$ emissions related to energy consumption in China did not significantly change, although they did decrease annually in the manufacturing sector. This trend indicates that in recent years, the Chinese manufacturing sector has utilized a lower amount of carbon energy. 
As the world's largest $\mathrm{CO}_{2}$ emitter [3], China is the key player in the field of climate change. The primary driver of its emissions is the industrial sector, including manufacturing [4]. The Chinese government is attempting to reduce $\mathrm{CO}_{2}$ emissions by promoting renewable energy investment [5]. However, the $\mathrm{CO}_{2}$ emissions-reduction effect is limited by the government's focus on shifting to renewable energy sources because in 2010 , the share of emissions produced by primary energy was only $8.3 \%$ [6]. Simultaneously, both energy efficiency and energy generation in the manufacturing sector are important for reducing $\mathrm{CO}_{2}$ emissions [7]. The manufacturing sector's $\mathrm{CO}_{2}$ emissions are primarily generated by fossil-fuel combustion. Therefore, the $\mathrm{CO}_{2}$ emissions produced by manufacturing firms reflect both their energy efficiency and their total energy consumption.

The political targets and energy-saving activities of China's eleventh Five Year Plan are the primary reasons for the manufacturing sector's improvements in energy intensity and carbon intensity [8]. The six policy orientations of China's eleventh Five Year Plan included the following: (1) conserving resources and protecting the environment and (2) enhancing capability for independent innovation. Additionally, there were nine major objectives based on these policy orientations, including the following: (1) significantly increasing resource utilization efficiency and (2) enhancing sustainable development. Both of those objectives focus on efficient energy consumption and greenhouse gas (GHG) reduction [9]. These clear political targets provide incentives for local governments and decision makers in manufacturing firms to promote energy saving and GHGreduction activities [10]. To achieve its nine major energy-saving objectives, China's eleventh Five Year Plan outlined specific activities: (1) ten key projects, (2) energy conservation planning for the top 1,000 enterprises, and (3) closing inefficient small-unit power plants [11].

Many scholars are interested in the policies of the eleventh Five Year Plan because of their impressive results in terms of both economic development and energy savings. However, most previous studies on economic development and energy savings during China's eleventh Five Year Plan have used provincial data or industrial data $[4,12,13]$, whereas research relying on corporate 
firm-level data remains scarce [11,14]. Our primary concern is that the firm-level industrial or regional characteristics that we intend to reveal might be both numerous and heterogeneous [15].

Firm-level ex post studies are lacking because energy consumption data for Chinese firms are not included in the well-known National Bureau of Statistics above-standard firm survey database; nor are they generally available. Although the 1,000 enterprises conservation project has provided the National Development and Reform Commission with detailed energy consumption information, these data are not available to researchers. In general, it is difficult to collect firm-level energy consumption and $\mathrm{CO}_{2}$ emissions data in China. That said, because energy procurement strongly affects production costs, each firm's business managers both determine the amount of energy used and select the energy source. Thus, each firm's energy-use data reflect its corporate strategy, which includes external factors such as environmental policies and energy prices. In this sense, we believe that it is important to focus on changes in corporate financial and environmental performance to understand the impact of China's eleventh Five Year Plan.

Additionally, industrial characteristics affect the relationship between $\mathrm{CO}_{2}$ emissions and corporate financial performance because the technical difficulty of reducing $\mathrm{CO}_{2}$ emissions varies across industries [16]. Furthermore, the capital equipment and labor requirements for reducing $\mathrm{CO}_{2}$ emissions vary across industries because the types of fuel consumed as intermediate materials also vary [17]. Therefore, industrial characteristics provide important information for creating effective energy saving and $\mathrm{CO}_{2}$ reduction policies in each industry.

Based on this background, we utilized a unique firm-level dataset on financial and environmental performance changes from 2005 to 2009 to conduct an ex post evaluation of the eleventh Five Year Plan. We focus on the characteristics of manufacturing firms that are identified as technical innovators. We examine the corporate financial and $\mathrm{CO}_{2}$ emissions data collected along with a unique questionnaire survey specifically focusing on energy use. The novelty of this study is the development of a framework for identifying corporate performance using the change in VA data, $\mathrm{CO}_{2}$ emissions data, and total factor productivity (TFP) estimated using the production function approach. We believe that this framework contributes to understanding both environmental and financial change 
in manufacturing firms considering industrial characteristics. This information is useful for creating effective climate-change mitigation policies that consider corporations' financial positions.

The remainder of this paper is organized as follows. Section 2 describes our methodology. Section 3 details the questionnaire and the dataset employed. The results on technical innovators and corporate performance identification are discussed in Section 4, and Section 5 concludes.

\section{Methodology}

This study measured TFP in terms of $\mathrm{CO}_{2}$ emissions. Using a directional distance function (DDF) and the Luenberger Productivity Indicator (hereafter, productivity indicator), we estimate TFP. A DDF evaluates productive efficiency using a nonparametric production function. The productivity indicator is considered a more general measure than the widely used Malmquist Index [18]. We can decompose a change in the productivity indicator into technical change (TECHCH) and efficiency change (EFFCH). These two indicators are useful for understanding the structure of TFP change [19].

\section{2-1. Directional Distance Function (DDF)}

Let $x \in \mathfrak{R}_{+}^{\mathrm{L}}, b \in \mathfrak{R}_{+}^{\mathrm{R}}$, and $y \in \mathfrak{R}_{+}^{\mathrm{M}}$ be the vectors for inputs, environmental outputs (or undesirable outputs), and market outputs (or desirable outputs), respectively. Define the production technology as

$$
\mathrm{P}(x)=\{(x, y, b): x \text { can produce }(y, b)\}
$$

We assume that good and bad outputs are null-joint; a firm cannot produce desirable outputs without producing undesirable outputs.

$$
(y, b) \in \mathrm{P}(x) ; b=0 \Rightarrow y=0 .
$$

We also assume weak disposability, which implies that the pollutant should not be considered freely disposable. ${ }^{1}$

\footnotetext{
${ }^{1}$ According to Fujii et al. [2], before defining the directional vectors in a productivity analysis that considers undesirable outputs, either strong disposability or weak disposability must be assumed. The difference between the strong and weak disposability of undesirable outputs is attributed to the opportunity cost of pollution abatement. Strong disposability assumes the undesirable output is not regulated and a firm can freely dispose of it. Otherwise, regulation on the undesirable output should potentially cause the firm to incur a disposal
} 


$$
(y, b) \in \mathrm{P}(x) \text { and } 0 \leq \beta \leq 1 \Rightarrow(\beta y, \beta b) \in \mathrm{P}(x) .
$$

According to the null-joint hypothesis and weak disposability, the DDF for firm $k$ can be computed by solving the following optimization problem:

$$
\begin{aligned}
& \overrightarrow{\mathrm{D}}\left(x_{k}^{l}, y_{k}^{m}, b_{k}^{r}, \mathrm{~g}_{x^{l}}, \mathrm{~g}_{y^{m}}, \mathrm{~g}_{b^{r}}\right)=\text { Maximize } \beta_{k} \\
& \text { s.t. } \quad \sum_{i=1}^{\mathrm{N}} \lambda_{i} x_{i}^{l} \leq x_{k}^{l}+\beta_{k} \mathrm{~g}_{x^{l}} \quad l=1, \cdots, \mathrm{L} \\
& \sum_{i=1}^{\mathrm{N}} \lambda_{i} y_{i}^{m} \geq y_{k}^{m}+\beta_{k} \mathrm{~g}_{y^{m}} \quad m=1, \cdots, \mathrm{M} \\
& \sum_{i=1}^{\mathrm{N}} \lambda_{i} b_{i}^{r}=b_{k}^{r}+\beta_{k} \mathrm{~g}_{b^{r}} \quad r=1, \cdots, \mathrm{R} \\
& \lambda_{i} \geq 0 \quad(i=1, \cdots, N),
\end{aligned}
$$

where $\beta_{k}$ is the production inefficiency score of the $\mathrm{k}^{\text {th }}$ firm and $\lambda_{i}$ is the weight variable to identify the reference point on the production frontier line. Here, $l, m$, and $r$ are the inputs, desirable outputs, and undesirable outputs, respectively; $x$ is the production input factor in the $\mathrm{L} \times \mathrm{N}$ input factor matrix; $y$ is the desirable output in the $\mathrm{M} \times \mathrm{N}$ desirable output factor matrix; and $b$ is the undesirable output factor in the $\mathrm{R} \times \mathrm{N}$ undesirable output matrix. In addition, $\mathrm{g}_{x}$ is the directional vector of the input factor, $\mathrm{g}_{y}$ is the directional vector of the desirable output factors and $\mathrm{g}_{b}$ is the directional vector of the undesirable output factors. To estimate the inefficiency scores of all of the firms, we must independently apply the model $\mathrm{N}$ times for each firm.

\section{2-2. Productivity Indicator}

TFP is computed from the results of the distance function model and is derived as follows [18]:

$$
\mathrm{TFP}_{\mathrm{t}}^{\mathrm{t}+1}=\mathrm{TECHCH}_{\mathrm{t}}^{\mathrm{t}+1}+\mathrm{EFFCH}_{\mathrm{t}}^{\mathrm{t}+1}
$$

\footnotetext{
cost. As indicated in the previous section, the Chinese government pressured manufacturing firms to reduce $\mathrm{CO}_{2}$ emissions. Thus, we
} consider weak disposability as the appropriate assumption to evaluate productive inefficiency incorporating $\mathrm{CO}_{2}$ emissions. 


$$
\begin{aligned}
& \operatorname{TECHCH}_{\mathrm{t}}^{\mathrm{t}+1}=\frac{1}{2}\left\{\overrightarrow{\mathrm{D}}^{\mathrm{t}+1}\left(x_{\mathrm{t}}, y_{\mathrm{t}}, b_{\mathrm{t}}\right)+\overrightarrow{\mathrm{D}}^{\mathrm{t}+1}\left(x_{\mathrm{t}+1}, y_{\mathrm{t}+1}, b_{\mathrm{t}+1}\right)-\overrightarrow{\mathrm{D}}^{\mathrm{t}}\left(x_{\mathrm{t}}, y_{\mathrm{t}}, b_{\mathrm{t}}\right)-\overrightarrow{\mathrm{D}}^{\mathrm{t}}\left(x_{\mathrm{t}+1}, y_{\mathrm{t}+1}, b_{\mathrm{t}+1}\right)\right\} \\
& \mathrm{EFFCH}_{\mathrm{t}}^{\mathrm{t}+1}=\overrightarrow{\mathrm{D}}^{\mathrm{t}}\left(x_{\mathrm{t}}, y_{\mathrm{t}}, b_{\mathrm{t}}\right)-\overrightarrow{\mathrm{D}}^{\mathrm{t}+1}\left(x_{\mathrm{t}+1}, y_{\mathrm{t}+1}, b_{\mathrm{t}+1}\right)
\end{aligned}
$$

where $x_{\mathrm{t}}$ represents the input for year $\mathrm{t}, x_{\mathrm{t}+1}$ is the production input for year $\mathrm{t}+1, y_{\mathrm{t}}$ is the desirable output for year $\mathrm{t}, y_{\mathrm{t}+1}$ is the desirable output for year $\mathrm{t}+1, b_{\mathrm{t}}$ is the undesirable output for year $\mathrm{t}$, and $b_{\mathrm{t}+1}$ is the undesirable output for year $\mathrm{t}+1$. Here, $\overrightarrow{\mathrm{D}}^{\mathrm{t}}\left(x_{\mathrm{t}}, y_{\mathrm{t}}, b_{\mathrm{t}}\right)$ is the production inefficiency score for year $\mathrm{t}$ based on the frontier line for year t. Similarly, $\overrightarrow{\mathrm{D}}^{\mathrm{t}+1}\left(x_{\mathrm{t}}, y_{\mathrm{t}}, b_{\mathrm{t}}\right)$ is the production inefficiency for year $t$ based on the frontier line for year $t+1$.

The TFP score indicates the productivity change relative to the benchmark year. TFP includes all types of productivity change, which are divided into technical change (TECHCH) and efficiency change (EFFCH). TECHCH shows shifts in the production frontier, whereas EFFCH indicates changes in a production unit's position relative to the frontier (i.e., catching up). Using these two indicators, we can identify the structure of productivity change as three types: frontier shift, catch-up, and overall improvement [20].

First, the catch-up type is defined by increasing EFFCH. In catch-up productivity change, an inefficient firm's productivity improvement is faster than an efficient firm's technological progress, and the efficiency gap shrinks. Second, the frontier shift type is defined by positive TECHCH and negative EFFCH. In the frontier shift type, productive and efficient firms on the frontier achieve technological progress. However, inefficient firms do not keep up with this technological development; therefore, the efficiency gap increases. Finally, the overall improvement type is defined by a TECHCH that is positive and an EFFCH that is close to zero. In the overall improvement of productivity change, the speed of the efficient firm's technological progress is nearly equal to that of the inefficient firm's productivity improvement.

In general, a productivity change estimation that applies a DDF model assumes either constant returns to scale (CRS) or variable returns to scale (VRS). We assumed CRS to avoid infeasible linear programming calculations in the time series analysis that are needed to estimate the productivity indicator. For example, Färe and Grosskopf [21] note that it is not always possible to compute 
productivity change in the VRS model. The linear programming calculation of time series analysis under VRS was infeasible in this study and therefore, we used only the CRS model.

To estimate the productivity change indicators, we set the directional vector $=\left(\mathrm{g}_{x^{l}}, \mathrm{~g}_{y^{m}}, \mathrm{~g}_{b^{r}}\right)=$ $\left(0, y_{k}^{m},-b_{k}^{r}\right)$. This type of directional vector assumes that an inefficient firm can decrease productive inefficiency while increasing desirable outputs and can decrease undesirable outputs in proportion to the initial combination of actual outputs.

As set above, the proportional directional vector measures the distance from each Chinese manufacturing firm to a frontier line focusing the percentage by which each firm can simultaneously increase desirable output and decrease undesirable output. The advantage of the proportional directional vector is that the reader can easily understand the inefficiency score. The inefficiency score represents the percentage by which each firm can increase desirable output and decrease undesirable output compared to the frontier line. Therefore, the proportional directional vector enables an inefficiency score that is independent from the unit of data. Additionally, the proportional directional vector provides an advantage in understanding TFP change. The TFP change indicator estimated by the proportional directional vector directly represents the percentage of production inefficiency change.

\section{2-3. Technical Innovators}

Recently, Kerstens and Managi [22] and Fujii et al. [23] have developed an identification method for technical innovators using productivity indicators. ${ }^{2}$ The notion of a technical innovator has been discussed since its introduction by Färe et al. [24]. We define a technical innovator (TI) from year $t$ to year $t+1$ using three conditions: (1) there are efficient observations in year $t+1$ (i.e., $\left.D^{t+1}\left(x_{t+1}, y_{t+1}, b_{t+1}\right)\right)$; (2) the productive efficiency level in year $t+1$ is beyond the production frontier line in year $\mathrm{t}\left(D^{t+1}\left(x_{t}, y_{t}, b_{t}\right)<0\right)$; and (3) the production frontier line is shifted in a more efficient direction $\left(\right.$ TECHCH $\left.{ }^{t, t+1}>0\right)$. Thus, we define an innovator using equation (12).

\footnotetext{
${ }^{2}$ Kerstens and Managi [22] and Fujii et al. [23] apply both convex and non-convex production technology assumption to identify the global and local technical innovator. Their study does not treat the undesirable output in production inefficiency evaluation by the DDF. According to Fujii et al. [2], strict assumptions about production technology such as variable return to scale and non-convex technology increase the cases of infeasible solutions in a production inefficiency estimation. We observed an infeasible solution if we assume nonconvex production technology. Thus, this study assumes convex production technology and identifies the technical innovator.
} 


$$
\operatorname{TI}\left(\left(x_{t}, y_{t}, b_{t}\right)\left(x_{t+1}, y_{t+1}, b_{t+1}\right)\right)=\left\{\begin{array}{c}
D^{t+1}\left(x_{t+1}, y_{t+1}, b_{t+1}\right)=0 \\
\cap D^{t+1}\left(x_{t}, y_{t}, b_{t}\right)<0 \\
\cap T E C H C H^{t, t+1}>0
\end{array}\right\}
$$

A firm satisfying the three conditions simultaneously described by equation (12) is identified as a technical innovator. We focus on the distribution of firms that are determined to be technical innovation firms by firm scale, location, and industrial characteristics.

Figure 2 graphically represents the technical innovator using input $(x)$ and output $(y)$ to provide a simple explanation of a technical innovator. In Figure 2, there are five firms in year $\mathrm{t}$ and year $\mathrm{t}+1$. In this case, firms $\mathrm{C}$ and $\mathrm{E}$ are technical innovators from year $\mathrm{t}$ to year $\mathrm{t}+1$ because they satisfy the three conditions.

$<$ Figure 2 about here>

\section{Data}

We used survey data collected by the Chinese Academy of Social Science and the China in the World Economy Center at Tsinghua University. The survey was conducted by the investigators through faceto-face interviews in 2010 with the support from local Development and Reform Commission, and the retrospective data from 2005 to 2009 provide a balanced panel of 800 firms $^{3}$ covering six provinces, Jiangsu, Shandong, Shanxi, Hebei, Jilin, and Sichuan, representing China's eastern, western, central, northeastern and southwestern areas. The firms cover a wide range of industries, including three extractive industries, electricity, food and beverages, textiles, equipment, pulp and paper, chemicals, and communications. Firm representatives answered various quantitative and qualitative questions regarding their firms' energy-use behaviors.

\footnotetext{
${ }^{3}$ We surveyed total 1,000 firms by randomly drawing samples from the NBS industrial survey database which include firms above-standard (above five mil. Yuan output value), about 200 firms were excluded from our survey since some data in these firms are incomplete or not consistent with the NBS industrial survey data, so total 800 firms are effective samples.
} 
For this analysis, we exclude several industries with small samples because of the limitations of the DDF approach. ${ }^{4}$ After excluding small-sample industries, data are available for 562 firms. Our dataset includes a balanced panel of 562 firms annually from 2005 to 2009, which includes the first four years of China's eleventh Five Year Plan. The firms span twelve industries, including food processing, textiles, pulp and paper, chemicals, cement, iron and steel, metals, general machines, special machines, transportation equipment, electric products, and computers. ${ }^{5}$

The variables used in this study include VA, labor cost, capital stock, and $\mathrm{CO}_{2}$ emissions. Monetary data are deflated to 2005 prices using sectoral deflators. To analyze productive inefficiency using the DDF approach, we use VA as the desirable output variable and labor cost and capital stock as market input variables. $\mathrm{CO}_{2}$ emissions data are used as undesirable outputs in the productive inefficiency estimation.

We calculate firms' $\mathrm{CO}_{2}$ emissions using energy consumption data from the survey and the carbon intensity of each energy good. $\mathrm{CO}_{2}$ emissions intensity is calculated based on the carbon embodied both in electricity and in the direct use of fossil fuels. Our carbon combustion coefficients are based on the 2006 Intergovernmental Panel on Climate Change Guidelines for National Greenhouse Gas Inventories [25]. The National Development and Reform Commission uses this method to guide the calculation of regional carbon intensity associated with regional electricity generation. We adopted the same method and computed the average carbon emissions factor for 16 energy types (including raw coal, coke, coal gas, crude oil, kerosene, and gasoline) and seven electricity grids in China. Carbon content, carbon oxidation rate, fuel emissions factor, and average net calorific value all differentiate the regional carbon intensity of China's electricity grid. Own-plant electricity generation was not considered explicitly in our calculation because it was not reported separately from grid-supplied electricity in the survey.

Table 1 provides the firm-level average scores from 2005 to 2009 by type of industry. Table 1 shows that $\mathrm{CO}_{2}$ emissions are high for the chemical, cement, and iron and steel industries. These three

\footnotetext{
${ }^{4}$ Cook et al. [32] discuss the limitations of the non-parametric production frontier approach as follows: "it is likely that a significant portion of decision-making units (DMUs) will be deemed as efficient if there are too many inputs and outputs given the number of DMUs." Nonparametric frontier analysis, including the DDF approach, experiences difficulty in evaluating productive inefficiency in small-sample datasets.

${ }^{5}$ Industry type is determined by the two-digit industry codes provided by the National Bureau of Statistics of China.
} 
industries are also characterized by low VA to $\mathrm{CO}_{2}$ emissions, whereas electronic products and computers are high-VA industries. This difference is caused by industry variation in the main energy sources used for production. For example, the iron and steel industry uses coal as a fuel and for oxidation-reduction reactions in shaft furnaces. In this case, without technological innovation in the intermediate material technology, it is difficult to reduce coal consumption while maintaining a constant level of steel production.

$<$ Table 1 about here>

To understand the firm scale and regional effects, we separate the firms by scale and location. First, we divided the sample into four groups by production size: large, medium, small, and tiny. Firms that on average employed more than 1,000 people from 2005 to 2009 are considered large. Firms with 300 to 999 employees are considered medium. Firms with 100 to 299 employees are considered small, and firms with less than 99 employees are considered tiny.

Table 2 shows firm samples by type of industry, province, and firm scale groups. In this study, large, medium, small, and tiny companies represent $9 \%, 23 \%, 47 \%$, and $21 \%$ of firms, respectively. Regarding the regional distribution of sample firms, Jiangsu, Shandong, Shanxi, Hebei, Jilin, and Sichuan provinces represent $14 \%, 5 \%, 27 \%, 26 \%, 17 \%$, and $11 \%$ of the total number of sample firms, respectively.

<Table 2 about here>

\section{Results}

The results are shown in Figures 3 and 4 and Tables 3 through 8 . To investigate productivity changes in these manufacturing firms, we set the base year to 2005. TFP, EFFCH, and TECHCH equal zero in the base year both in Table 3 and in Figures 3 and 4. 


\section{4-1. TFP Change}

Figures 3 and 4 and Table 3 show TFP changes from 2005 to 2009 by industry. TFP changes in daily commodities and basic material industries are described in Figure 3, whereas TFP changes for the processing and assembly industries are described in Figure 4. Table 3 shows total TFP changes from 2005 to 2009 by industry. In Table 3, we also describe the structure of TFP change, applying the identification method explained in Section 2-2. Figure 3 indicates that from 2007 to 2008 the TFP of the textiles and metals industries increased, whereas the TFP of the food, paper, and steel industries rapidly decreased .

We now discuss the results for the processing and assembly industries (see Figure 4). TFP increased rapidly in the computer industry; however, other industries' TFP did not improve from 2005 to 2009. Furthermore, TFP increased more rapidly from 2007 to 2008 in the processing and assembly industries than in the basic materials industries. One explanation for this rapid TFP growth is the technological innovations in the information technology field, which would also have affected the precision machinery and electronic components industries.

$<$ Figure 3 about here>

$<$ Figure 4 about here>

Next, we consider the structure of TFP change. Table 3 provides the results of the TFP, $\mathrm{EFFCH}$, and TECHCH estimations. As indicated above, the DDF model with a proportional directional vector enables us to understand the percentage change of each firm's productivity change. Table 3 provides the productivity change scores by type of industry. Table 3 indicates that on average, the food industry decreases its TFP score by 0.068 . These results show that on average, food manufacturing firms decrease $6.8 \%$ of their VA and increase $6.8 \%$ of their $\mathrm{CO}_{2}$ emissions without changing input amount from 2005 to 2009.

Table 3 indicates that the improvement in TFP is primarily caused by growth in EFFCH from 2005 to 2009 in the eight manufacturing industries. In particular, the cement, transportation 
equipment, and computer industries achieved positive TFP change from 2005 to 2009 because of EFFCH growth caused by the catching up of inefficient firms. Meanwhile, the main factor involved in increased TFP was improved TECHCH in the steel, metal, and general machine industries. Finally, only the textiles industry exhibited overall improvement attributable to both EFFCH and TECHCH from 2005 to 2009: the production frontier line shifted in a more efficient direction and the gap between the frontier line and inefficient firms decreased in the textiles industry.

Two main factors affected TFP change in the Chinese manufacturing sector. The first was the financial crisis triggered by the collapse of Lehman Brothers (on September 15, 2008). Fujii et al. [26] note that this serious financial crisis forced many manufacturing firms around the world to reduce their production scale in response to decreased market demand. This decrease in economic scale critically affected manufacturing firms, particularly production frontier companies that had a sufficient technological advantage to export their products. Thus, we observe a negative TECHCH indicator in the Chinese manufacturing sector from 2005 to 2009.

The second factor was China's strong environmental policy. Three industries—steel, metals, and general machines-achieved positive TECHCH and are identified as frontier shift industries. These three industries are energy intensive. We assume that environmental policy related to energy conservation laws affected TFP growth because of the TECHCH increase in these energy-intensive industries. According to $\mathrm{Xu}$ et al. [12], 69 energy-utilization policies, 30 industry-restructuring policies, and 26 fuel-mix shift policies were enforced in China from 2004 to 2012. More specifically, energy-inefficient firms were targeted by the industrial restructuring policies, which phased out obsolete capacity in energy-intensive industries, such as iron and steel, coke, and cement. The Chinese government established the closure criteria according to industry type [27]. In addition, export rebates were substantially reduced for these sectors. Local government officials' performance evaluations were also linked to local energy conservation targets, whereas the 1,000 firms program linked manager promotions to firms' energy-saving performance. Overall, these strong environmental measures played an important role in promoting energy conservation and $\mathrm{CO}_{2}$ emissions reduction among manufacturing companies, particularly in energy-intensive industries. 
$<$ Table 3 about here>

\section{4-2. Technical Innovators}

We now discuss the innovator firms identified by the DDF approach. Tables 4 and 5 describe the results of the innovator identification analysis.

Table 4 shows the number of innovator firms by year and firm scale. The numbers in parentheses indicate the proportion of the total number of firms. ${ }^{6}$ The bottom line of Table 4 represents the total number of innovators and the related proportion in 12 industries. These results indicate that technical innovators are primarily observed after 2006. Next, we focus on individual industry results. Four industries - textiles, paper, steel and computers—included several innovators. Therefore, the production frontiers of these four industries shifted because of the technical improvement of many innovator firms. Meanwhile, the composition of firm scale varied among these four industries. Large-scale firms in the textiles industry tend to be identified as innovators more often than in other industries. However, innovators in the steel and computer industries are members of the small and tiny groups.

$<$ Table 4 about here>

Next, we discuss the results for innovators by firm location. Table 5 displays the number of innovator firms by province. The figures in parentheses indicate the proportion of innovators. ${ }^{7}$ Of the 12 industries listed in Table 5, manufacturing firms located in Jiangsu, Shanxi, Hebei, and Jilin tend to be innovators. Meanwhile, fewer innovator firms are located in Shandong and Sichuan than in the other provinces. Additionally, the tendencies of innovators in each province vary by industry. A significant number of firms in the textile and steel industries located in Jiangsu are considered

\footnotetext{
${ }^{6}$ The figures in parentheses in the breakdown by firm scale are calculated as the number of innovators in each scale group's total number of firms multiplied by four. This method is chosen because the numerators are defined as the total number of innovators over the four periods. Thus, the denominators of the figures in parentheses differ from the numbers of innovators by year and the number of innovators by firm scale in Table 4.

${ }^{7}$ We estimate the share as the number of innovators divided by each provincial firm multiplied by four because the numerator is defined as the total number of innovators over the four periods.
} 
innovators; in particular, nearly half of steel firms are considered innovators in Jiangsu. In Shanxi and Hebei, there is an even distribution of innovator firms across the 12 industries.

The trend for innovator identification varies because of the timing of the adoption of energysaving policies. Zheng et al. [28] note that local energy-saving policies were adopted in 1997 for Shandong, in 2000 for Jiangsu, and in 2000 for Sichuan. Jilin adopted these policies in 2003, and Hebei and Shanxi adopted them in 2006. Thus, Jilin, Hebei, and Shanxi had enough time to potentially improve energy efficiency in 2005 because energy-saving policies were introduced later there than in the other three provinces. Additionally, Shanxi Province introduced its own energy conservation program, the Top 200 Energy-Consuming Enterprises Program (Top 200 Program). ${ }^{8}$ This program also helped high energy-consuming manufacturing companies improve their energy efficiency.

According to $\mathrm{Yu}$ et al. [27], the main player in the enforcement of energy efficiency policies has shifted since 2006 from the national government to local governments. Therefore, energy efficiency policies strongly depend on the provincial strategy, particularly with respect to industrial structure and cost effectiveness. Thus, productivity and energy efficiency improvement speeds differ across provinces because environmental policy enforcement by local governments is diverse.

$<$ Table 5 about here>

\section{4-3. Corporate Performance Identification Matrix}

Here, we discuss corporate performance focusing on the $\mathrm{CO}_{2}$ emissions reduction identified by TFP changes and the data from 2005 to 2009 . We consider the case in which the manufacturing firm can reduce $\mathrm{CO}_{2}$ emissions in the following three ways. First, there is efficiency improvement in the production process and weight savings in the product design that are caused by technological progress. In this case, firms can reduce $\mathrm{CO}_{2}$ emissions without sacrificing economic performance. Second, the introduction of energy-efficient production equipment contributes to reduced energy consumption and

\footnotetext{
${ }^{8}$ Zhang et al. [33] explain that the Top 200 Program was designed to improve energy efficiency in the industrial sector. It targets Shanxi's 200 highest energy-consuming enterprises (86 were also included in the National Top 1,000 Program), which accounts for nearly $80 \%$ of the total industrial sector's energy consumption and $65 \%$ of total energy consumption in Shanxi. The industries included in the Top 200 Program are large-scale enterprises in 6 major energy-consuming industries, each of which consumed a minimum of 100,000 tce in 2005.
} 
$\mathrm{CO}_{2}$ emissions. However, this investment might decrease financial performance because of worsening capital productivity. Third, scaling down production contributes to reduced $\mathrm{CO}_{2}$ emissions because of the energy consumption saved in the production process.

That notwithstanding, $\mathrm{CO}_{2}$ emissions will increase because of production scale expansion or product design shifting into high-energy-intensity goods. Under these assumptions, we can categorize corporate performance using TFP and data changes (Table 6). Table 6 shows the identification matrix for grouping corporate performance. We use two types of TFP changes: TFP change considering $\mathrm{CO}_{2}$ emissions $\left(\mathrm{TFP}_{\text {joint }}\right)$ and TFP change without considering $\mathrm{CO}_{2}$ emissions $\left(\mathrm{TFP}_{\text {market }}\right){ }^{9}{ }^{\mathrm{TFP}}$ market represents the conventional TFP measure, which reflects pure corporate financial performance. In addition to using two types of TFP changes, we examine sales data and $\mathrm{CO}_{2}$ emissions change data from 2005 to 2009 to determine corporate performance.

$<$ Table 6 about here>

Here, we explain the matrix using types 2 and 6 in Table 6. Firms identified as both types increase $\mathrm{TFP}_{\text {joint }}$ in addition to increasing sales and decreasing $\mathrm{CO}_{2}$ emissions. Firms identified as type 2 improved their labor productivity or capital productivity, as reflected by their increased $\mathrm{TFP}_{\text {market. }}$. Therefore, firms identified as type 2 achieve reductions in $\mathrm{CO}_{2}$ emissions without sacrificing economic performance.

Next, we discuss the type 6 case. Firms identified as type 6 experience increases in TFP $_{\text {joint }}$ and decreases in $\mathrm{TFP}_{\text {market }}$. These results imply that sales to $\mathrm{CO}_{2}$ emissions increased and that either labor productivity or capital productivity decreased. In this case, we can hypothesize that firms introduced energy-efficient equipment or increased labor input to conserve energy. Thus, we understand that firms identified as type 6 reduce their $\mathrm{CO}_{2}$ emissions at the expense of financial performance.

\footnotetext{
${ }^{9} \mathrm{TFP}_{\text {market }}$ is estimated using the DDF and the productivity indicator. To estimate $\mathrm{TFP}_{\text {market, }}$, we use equations (4) through (8) (with the exception of equation (7) in Section 2-1) to evaluate production inefficiency without considering $\mathrm{CO}_{2}$ emissions.
} 
The figures in parentheses in Table 6 show the number of identified firms and their proportion of the total 562 firms. As shown in Table 6, most of the firms are identified as types 1,2, 5, 13, 15, or 16. Overall, 483 firms can be identified as one of these six types, and they represent $86 \%$ of the total sample. Therefore, we discuss the number of firms identified as these six types focusing on firm scale and location. Before we discuss these results, we must consider each type. Type 2 is the most desirable pattern for both economic development and environmental protection. Although type 1 is good for economic development, it is undesirable in terms of environmental protection. Here, we categorize types 1 and 2 as the "improvement group." Moreover, type 5 contributes to expanding the Chinese economy but is undesirable from an economic standpoint because its financial performance worsens. Type 15 is undesirable because its product design changes for the purposes of environmental protection. Another possibility is that scale efficiency decreases because of the decreased capital equipment utilization caused by declining demand. Finally, the corporate performance of types 13 and 16 renders them non-competitive in the market. Because these three types have negative $\mathrm{TFP}_{\text {joint }}$ and $\mathrm{TFP}_{\text {market }}$ values, we call them the "worst group."

Tables 7 and 8 identify corporate performance by industry type, firm scale, and location. As shown in Table 7, firms in the processing and assembly industries tend to be either type 1 or type 13 . Thus, the processing and assembly industries increased their production scale from 2005 to 2009 . Meanwhile, the computer industry is composed of one-half type 1 and type 2 firms, i.e., firms that have achieved improvements in both $\mathrm{TFP}_{\text {joint }}$ and $\mathrm{TFP}_{\text {market }}$. Therefore, corporate performance in the computer industry improved.

One interpretation of these results is that the speed of technological development in the processing and assembly industries was much faster than in the basic material industries. For example, the price of personal computers decreased dramatically even though product performance remained the same. This is because new products with better performance are supplied in the market in rapid product cycles. Meanwhile, the prices of steel and petroleum products did not change because of performance, as technological development is slow. Therefore, industrial characteristics are one reason that we observe a large sample of firms in the improvement group in the processing and assembly industries. 
As shown in Table 8, many manufacturing firms in Jiangsu and Sichuan Provinces improved their financial and environmental performance. However, approximately one-half of the firms in Shandong and Shanxi Provinces were identified as belonging to the worst group. In particular, 19.4\% of the firms located in Shandong Province were identified as type 16, which implies that performance worsened because of the scaling down of production. One interpretation of the results in Shandong is that the 2008 financial crisis strongly affected manufacturing companies that exported to foreign countries. The global decrease in market demand attributable to the financial crisis caused TFP to decrease because of the low facility-operation rate from production adjustment [20].

Tables 7 and 8 show that there are clear differences in corporate performance trends by industry, location, and firm scale. These results imply that policy makers must consider the differences in the manufacturing firms' characteristics. By applying the corporate performance identification matrix, we can easily identify trends in both corporate environmental management and the economic situations of Chinese manufacturing firms. Additionally, this identification approach needs the datasets used for productivity analysis. We believe that this new approach is helpful for local government officers involved in environmental policy making to understand corporate performance with less cost and effort.

$<$ Table 7 about here>

$<$ Table 8 about here>

We believe that the performance identification matrix is a helpful tool to evaluate technology adoption in manufacturing companies. The Intergovernmental Panel on Climate Change [29] noted that "Effective adaptation and mitigation responses will depend on policies and measures across multiple scales: international, regional, national and sub-national. Policies across all scales supporting technology development, diffusion and transfer, as well as finance for responses to climate change, can complement and enhance the effectiveness of policies that directly promote adaptation and mitigation." Moreover, it is difficult to measure the adoption of technology. 
Haščič and Migotto [30] summarize the key advantages and limitations of the various measures of innovation (see Table 2 in Haščič and Migotto [30]). They note that patent data are useful for evaluating technology-development activities. Moreover, patent data have limitations related to evaluating technology adoption. Haščič and Migotto [30] suggest that the "proxy for improvements in environmental endpoints" has an advantage when evaluating technology adoption. Based on these discussions, we believe that our proposed corporate performance identification matrix provides information that is useful for evaluating the improvement in environmental endpoints considering both the economic situation and the technology adoption effect.

\section{Conclusions}

This study analyzes corporate financial and environmental performance in China considering firmlevel heterogeneity. We determine TFP change using the DDF approach and identify changes in corporate financial and environmental performance. Our conclusions can be summarized as follows.

First, significant numbers of technical innovators are observed in the textile, paper, steel, and computer industries from 2005 to 2009 . Technical innovators in the textile industry are large-scale firms; however, innovators in the steel and computer industries are small and tiny firms. Second, Jiangsu Province has many technical innovators, particularly in the textile and steel industries. Shanxi and Hebei Provinces have similar technical innovator trends. These two provinces have technical innovators in the paper, steel, and computer industries.

Third, firms in the processing and assembly industries not only are larger in scale but also experienced improved financial performance. Thus, the processing and assembly industries increased their production scale and gained market competitiveness from 2005 to 2009. Many manufacturing firms in Jiangsu and Sichuan Provinces improved their financial and environmental performance. However, approximately half of the firms in Shandong and Shanxi Provinces are part of the worst group. 
This new evidence regarding innovators and corporate performance identification is useful in establishing environmental standards and creating subsidy policies to achieve sustainable development. Additionally, productivity trends by industry, firm scale, and location characteristics could be helpful in evaluating the potential magnitude of not only major energy and environmental policies but also financial crises. We believe that this study's results and new identification approaches provide useful information for designing effective policies that balance economic development and environmental protection.

One real application of the identification framework results is to clearly distinguish among manufacturing firms. For example, firms identified as members of the innovator or improvement group may have the characteristics of successfully reducing $\mathrm{CO}_{2}$ emissions without sacrificing financial performance. Therefore, government or industrial associations could interview individuals from those firms and share the factors underlying their success in governmental seminars and business association workshops. This information-sharing activity is cost effective because it does not require a large budget.

Stern and Aronsson [31] note that an effective policy would include individual audits of companies to obtain specific information that will become more important to and necessary for manufacturing firms. Specifically, this information sharing system is helpful for small- and mediumscale firms that do not have enough human resources or equipment to improve energy efficiency and reduce $\mathrm{CO}_{2}$ emissions. In this sense, the identification research framework can play an important role in promoting information sharing activities more efficiently and effectively.

Further research is needed to analyze corporate performance and identify technical innovators in the gas and electricity sector, which has a strong impact on energy consumption in China. Such an analysis could suggest additional constructive policy implications to promote energy savings and reduce $\mathrm{CO}_{2}$ emissions without sacrificing economic development. 


\section{Acknowledgements}

This research was funded by a Grant-in-Aid for Specially Promoted Research [26000001B] from the Ministry of Education, Culture, Sports, Science and Technology (MEXT), Japan, National Science Foundation of China (Project Code: 71422013, 71173130), Tsinghua University Research Center for Green Economy and Sustainable Development, Tsinghua University Initiative Scientific Research Program, and Key Projects in the National Science \& Technology Pillar Program during the Twelfth Five-Year Plan Period (Project No. 2012BAC03B01). The results and conclusions presented in this article do not necessarily represent the views of the funding agencies.

\section{References}

[1] Fisher-Vanden K, Ho MS. How do market reforms affect China's responsiveness to environmental policy? J Dev Econ 2007;82:200-33. doi: 10.1016/j.jdeveco.2005.06.004.

[2] Fujii H, Kaneko S, Managi S. Changes in environmentally sensitive productivity and technological modernization in China's iron and steel industry in the 1990s. Environ Dev Econ 2010;15:485-504. doi: 10.1017/S1355770X10000173.

[3] Dai H, Mischke P, Xie X, Xie Y, Masui T. Closing the gap? Top-down versus bottom-up projections of China's regional energy use and $\mathrm{CO}_{2}$ emissions. Appl Energ 2016;162:1355-73. doi: 10.1016/j.apenergy.2015.06.069.

[4] Long R, Shao T, Chen H. Spatial econometric analysis of China's Province-Level Industrial carbon productivity and its influencing factors. Appl Energ 2015 in Press.

[5] Dai H, Xie X, Xie Y, Liu J, Masui T. Green growth: the economic impacts of large-scale renewable energy development in China. Appl Energ 2016;162:435-49. doi: 10.1016/j.apenergy.2015.10.049. 
[6] Gu A, Teng F, Lv Z. Exploring the nexus between water saving and energy conservation: insights from industry sector during the 12th five-year plan period in China. Renewable Sustain Energ Rev 2016;59:28-38. doi: 10.1016/j.rser.2015.12.285.

[7] Wang Z, Feng C. A performance evaluation of the energy, environmental, and economic efficiency and productivity in China: an application of global data envelopment analysis. Appl Energ 2015;147:617-26. doi: 10.1016/j.apenergy.2015.01.108.

[8] Zhou N, Levine MD, Price L. Overview of current energy-efficiency policies in China. Energ Policy 2010;38:6439-52. doi: 10.1016/j.enpol.2009.08.015.

[9] World Bank. Mid-term evaluation of China's $11^{\text {th }}$ five year plan. Report No. 46355-CN. Paris: World Bank; 2008.

[10] Price L, Levine MD, Zhou N, Fridley D, Aden N, Lu H, et al. Assessment of China's energysaving and emission-reduction accomplishments and opportunities during the 11th five year plan. Energ Policy 2011;39:2165-78. doi: 10.1016/j.enpol.2011.02.006.

[11] Cao J, Karplus VJ. Firm-level determinants of energy and carbon intensity in China. Energ Policy 2014;75:167-78. doi: 10.1016/j.enpol.2014.08.012.

[12] Xu J, Fan Y, Yu S. Energy conservation and $\mathrm{CO}_{2}$ emission reduction in China's $11^{\text {th }}$ five-year plan: A performance evaluation. Energ Econ 2014;46:348-59. doi: 10.1016/j.eneco.2014.10.013.

[13] Nielsen H. Productive efficiency in the iron and steel sector under state planning: the case of China and former Czechoslovakia in a comparative perspective. Appl Energ 2016 in press. doi: 10.1016/j.apenergy.2015.12.125.

[14] Fisher-Vanden K, Mansur ET, Wang Q((. Electricity shortages and firm productivity: evidence from China's industrial firms. J Dev Econ 2015;114:172-88. doi: 10.1016/j.jdeveco.2015.01.002.

[15] Holz CA. The unbalanced growth hypothesis and the role of the state: the case of China's stateowned enterprises. J Dev Econ 2011;96:220-38. doi: 10.1016/j.jdeveco.2010.10.007. 
[16] Kumar S, Fujii H, Managi S. Substitute or complement? Assessing renewable and nonrenewable energy in OECD countries. Appl Econ 2015;47:1438-59. doi: 10.1080/00036846.2014.997922.

[17] Fujii H, Managi S. Optimal production resource reallocation for $\mathrm{CO}_{2}$ emissions reduction in manufacturing sectors. Glob Environ Change 2015;35:505-13. doi: 10.1016/j.gloenvcha.2015.06.005.

[18] Chambers RG, Chung Y, Färe R. Profit, directional distance functions, and Nerlovian efficiency. J Optim Theor Appl 1998;98:351-64. doi: 10.1023/A:1022637501082.

[19] Managi S, Opaluch JJ, Jin D, Grigalunas TA. Technological change and depletion in offshore oil and gas. J Environ Econ Manag 2004;47:388-409. doi: 10.1016/S0095-0696(03)00093-7.

[20] Fujii H, Managi S, Kawahara H. The pollution release and transfer register system in the U.S. and Japan: an analysis of productivity. J Cleaner Prod 2011;19:1330-8. doi: 10.1016/j.jclepro.2011.01.010.

[21] Färe R, Grosskopf S. Intertemporal production frontiers: with dynamic DEA. Boston: Kluwer Academic Publishers; 1996.

[22] Kerstens K, Managi S. Total factor productivity growth and convergence in the petroleum industry: empirical analysis testing for convexity. Int J Prod Econ 2012;139:196-206. doi: 10.1016/j.ijpe.2012.04.008.

[23] Fujii H, Edamura K, Sumikura K, Furusawa Y, Fukuzawa N, Managi S. How enterprise strategies are related to innovation and productivity change: an empirical study of Japanese manufacturing firms. Econ Innov New Technol 2015;24:248-62. doi: 10.1080/10438599.2014.924746.

[24] Färe R, Grosskopf S, Norris M, Zhang Z. Productivity growth, technical progress and efficiency change in industrialized countries. Am Econ Rev 1994;84:66-83.

[25] Intergovernmental Panel on Climate Change (IPCC). IPCC guidelines for national greenhouse gas inventories. Volume 2: Energy, Table 1.3 and 1.4. Geneva: IPCC; 2006. 
[26] Fujii H, Assaf AG, Managi S, Matousek R. Did the financial crisis affect environmental efficiency? Evidence from the Japanese manufacturing sector. Environ econ. Policy Stud 2015. doi: 10.1007/s10018-015-0127-0, available at http://link.springer.com/article/10.1007/s10018015-0127-0.

[27] Yu Y, Wang X, Li H, Qi Y, Tamura K. Ex-post assessment of China's industrial energy efficiency policies during the11th five-year plan. Energ Policy 2015;76:132 - 45. doi: 10.1016/j.enpol.2014.11.010.

[28] Zheng S,Yi H, Li H. The impacts of provincial energy and environmental policies on air pollution control in China. Renewable Sustain Energ Rev 2015;49:386 - 94. doi: 10.1016/j.rser.2015.04.088.

[29] Intergovernmental Panel on Climate Change (IPCC). Climate change 2014: mitigation of climate change. IPCC fifth assessment report (AR5); 2014.

[30] Haščič I, Migotto M. Measuring environmental innovation using patent data: policy relevance. OECD Environment Working Papers. Paris: OECD Publishing; 2015.

[31] Stern PC, Aronson E, editors. Energy use: the human dimension. New York: Freeman; 1984, p. 237.

[32] Cook WD, Tone K, Zhu J. Data envelopment analysis: Prior to choosing a model. Omega 2014;44:1-4. doi: 10.1016/j.omega.2013.09.004.

[33] Zhang D, Aunan K, Seip H, Vennemo H. The energy intensity target in China's $11^{\text {th }}$ five-year plan period - Local implementation and achievements in Shanxi Province. Energ Policy 2011;39:4115-24. doi: 10.1016/j.enpol.2011.03.085. 


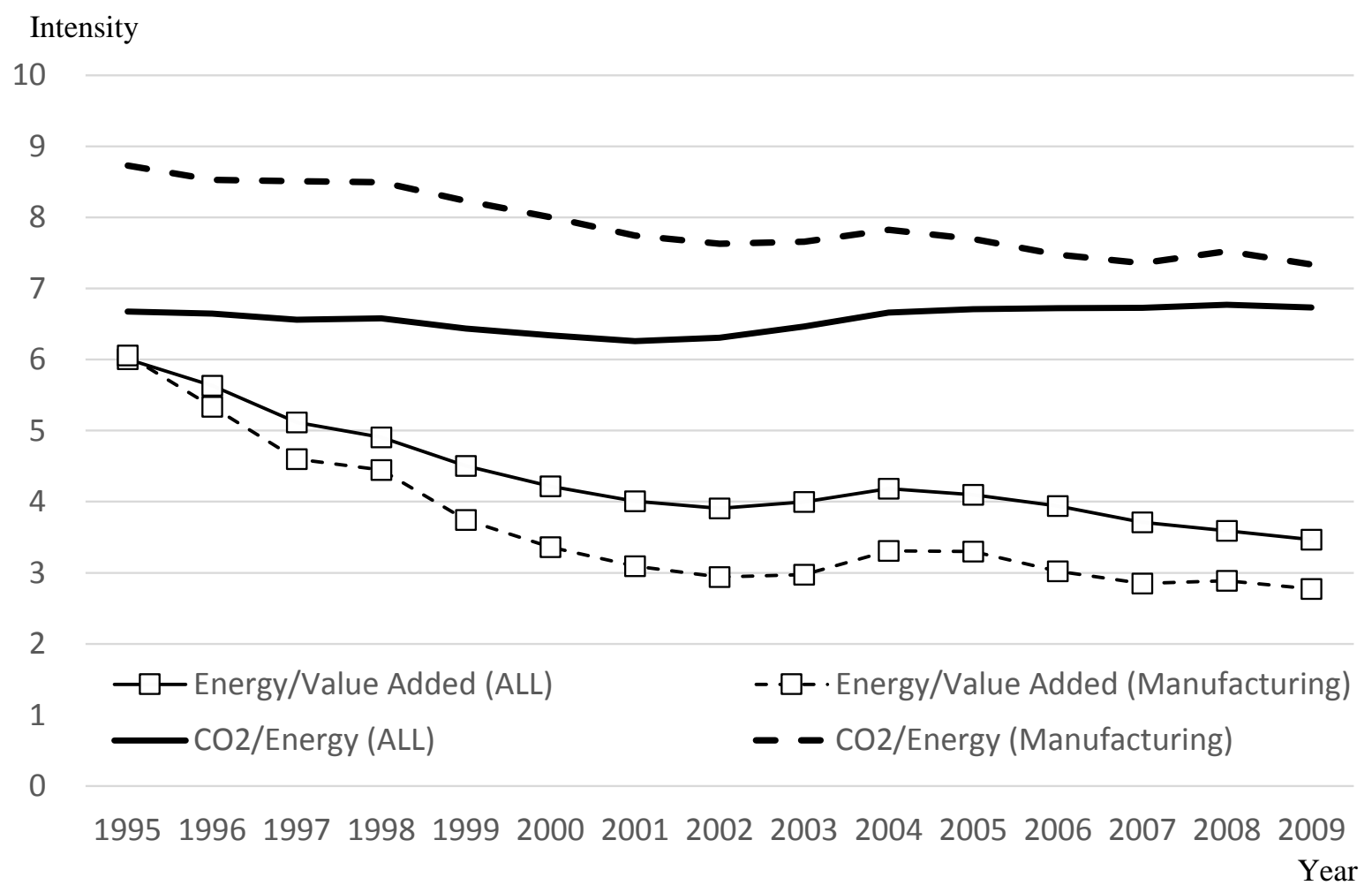

Figure 1. Carbon and energy-intensity trends in China

Note 1: Unit of value added per energy is millions of yuan per TJ.

Note 2: Unit of $\mathrm{CO}_{2}$ emissions per energy is 100 ton- $\mathrm{CO}_{2}$ per TJ.

Note 3: Value added is deflated to 2005 prices. 


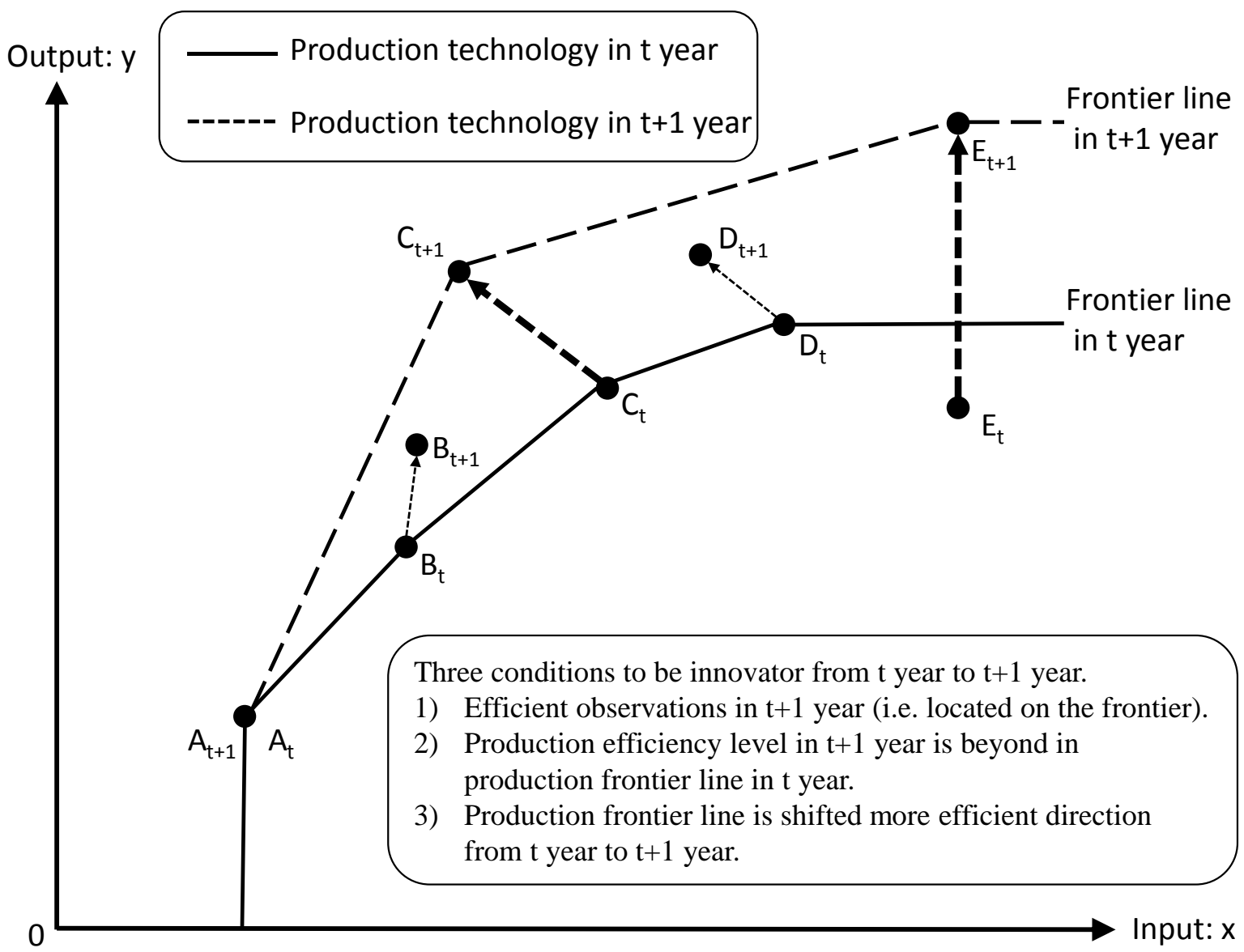

Figure 2. Graphical image of a technical innovator 


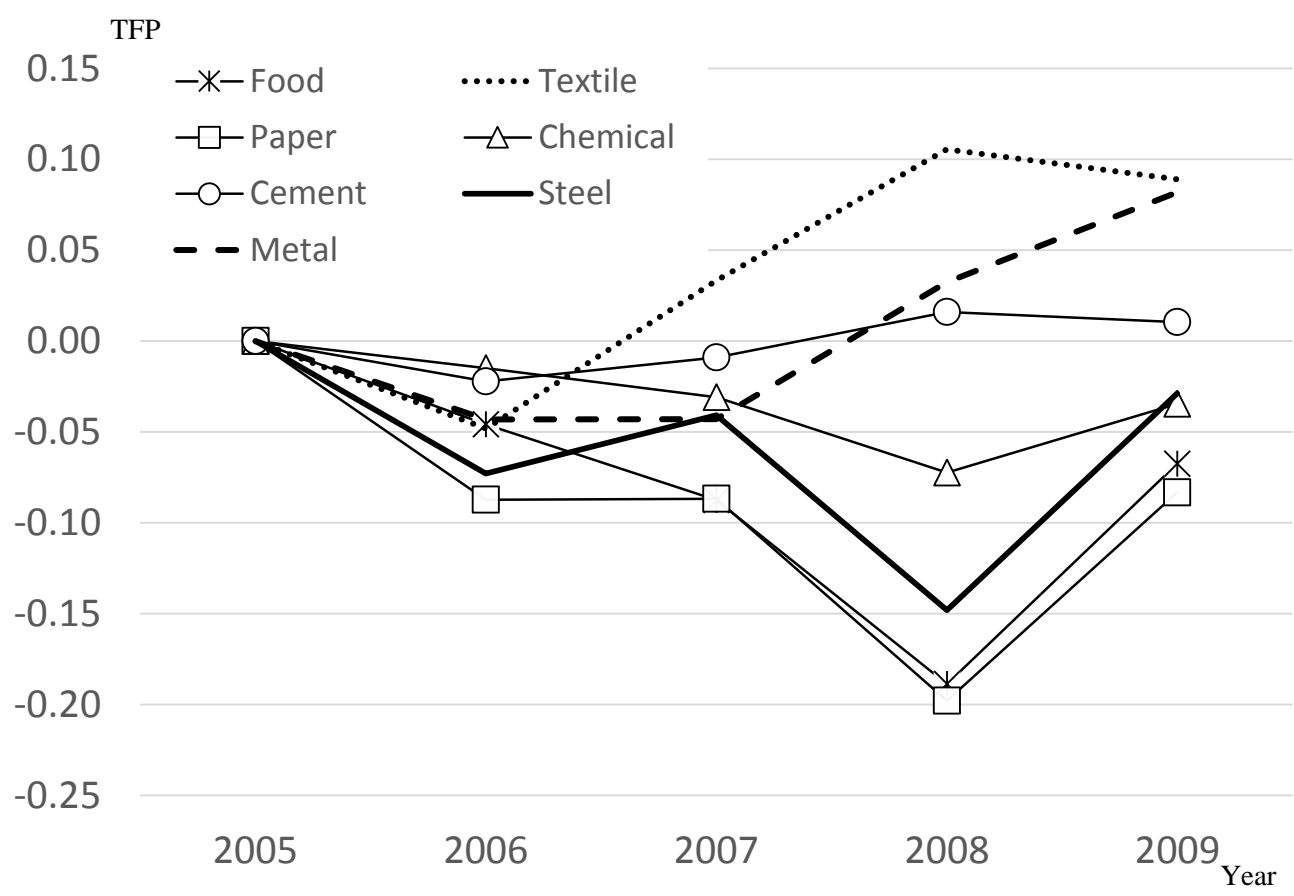

Figure 3. TFP change from 2005 to 2009 in the daily commodity and basic material industries

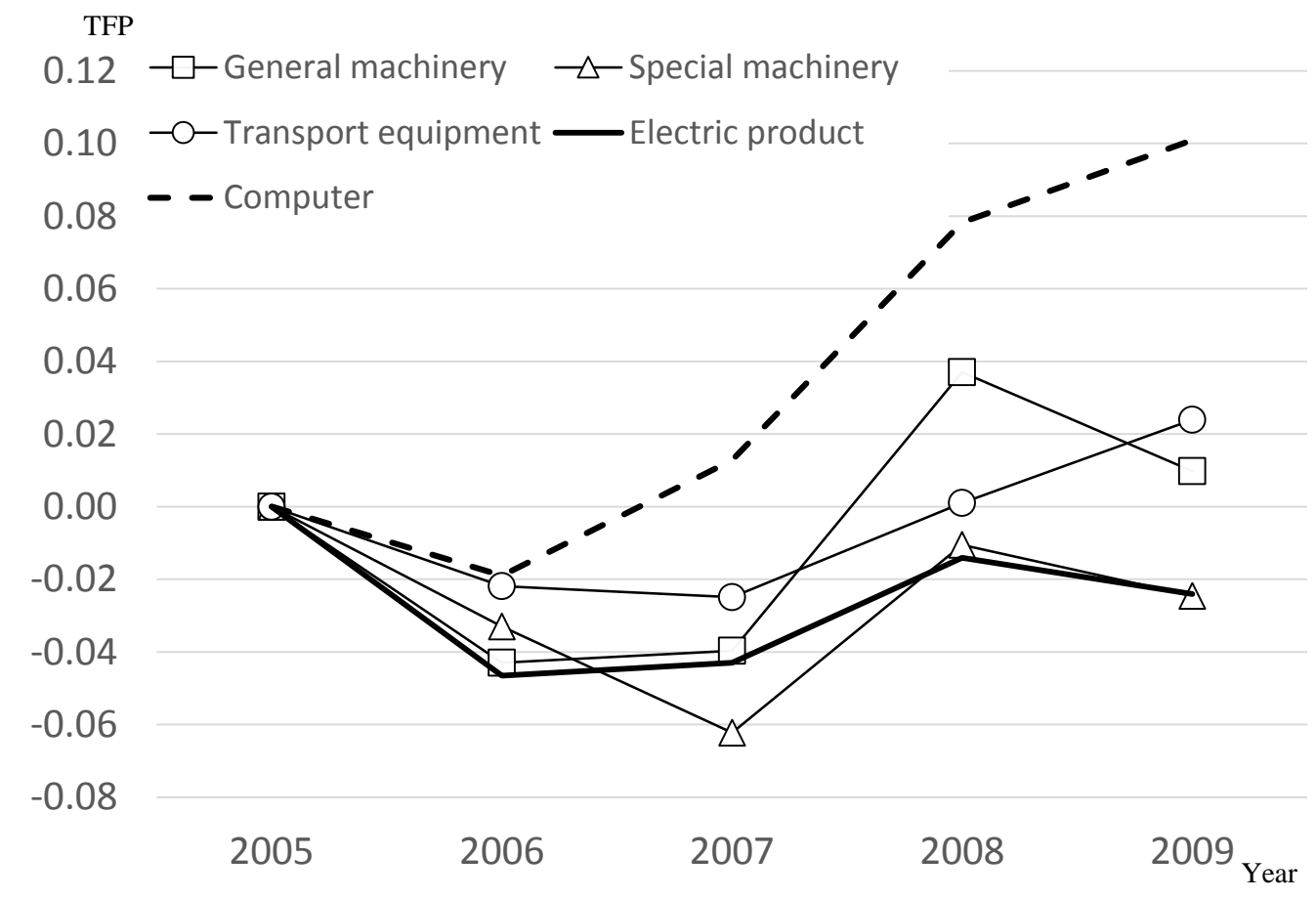

Figure 4. TFP change from 2005 to 2009 in the processing and assembly industries 
Table 1. Data description of each variable (average score per firm from 2005 to 2009)

\begin{tabular}{lcrrrrrrr}
\hline \multicolumn{1}{c}{ Industry name } & $\begin{array}{c}\text { \# of } \\
\text { firms }\end{array}$ & $\begin{array}{c}\text { Value } \\
\text { added (VA) }\end{array}$ & Labor & Capital & $\begin{array}{c}\mathrm{CO}_{2} \\
\text { emissions }\end{array}$ & $\begin{array}{c}\text { VA/ } \\
\text { Labor }\end{array}$ & $\begin{array}{c}\text { VA/ } \\
\text { Capital }\end{array}$ & $\begin{array}{c}\text { VA/ } \\
\mathrm{CO}_{2}\end{array}$ \\
\hline Food & 37 & 208,662 & 8,011 & 158,939 & 355 & 11.07 & 3.19 & 290.04 \\
Textiles & 35 & 64,141 & 9,783 & 74,803 & 251 & 5.21 & 2.87 & 276.67 \\
Paper & 20 & 23,351 & 3,865 & 17,049 & 242 & 7.12 & 3.88 & 285.41 \\
Chemical & 78 & 57,603 & 7,953 & 51,654 & 17,958 & 11.82 & 3.45 & 79.71 \\
Cement & 68 & 24,301 & 6,545 & 39,664 & 20,549 & 5.86 & 2.56 & 97.30 \\
Iron and steel & 30 & 236,449 & 17,819 & 373,468 & 108,803 & 8.38 & 2.14 & 10.21 \\
Metals & 33 & 21,000 & 5,621 & 21,155 & 684 & 3.91 & 3.06 & 226.32 \\
General machine & 95 & 35,510 & 6,597 & 28,061 & 1,340 & 6.05 & 4.32 & 217.16 \\
Special machine & 39 & 88,257 & 21,566 & 124,609 & 1,162 & 5.07 & 2.09 & 294.10 \\
Transportation equ. & 56 & 377,266 & 78,518 & 427,144 & 1,282 & 5.79 & 2.39 & 224.78 \\
Electric products & 49 & 81,745 & 7,220 & 45,365 & 211 & 8.05 & 2.93 & 342.88 \\
Computer & 22 & 15,443 & 16,754 & 147,867 & 312 & 9.67 & 2.78 & 523.31 \\
\hline
\end{tabular}

Note 1: Units of value added, labor, and capital are 1,000 yuan.

Note 2: Unit of $\mathrm{CO}_{2}$ emissions is ton- $\mathrm{CO}_{2}$.

Note 3: All monetary data are deflated to 2005 prices.

Table 2. Sample distribution by firm scale and province

\begin{tabular}{|c|c|c|c|c|c|c|c|c|c|c|}
\hline \multirow[b]{2}{*}{ Industry name } & \multicolumn{4}{|c|}{ Firm scale } & \multicolumn{6}{|c|}{ Firm location } \\
\hline & Large & Medium & Small & Tiny & Jiangsu & Shandong & Shanxi & Hebei & Jilin & Sichuan \\
\hline Food & 3 & 9 & 19 & 6 & 6 & 1 & 22 & 3 & 2 & 3 \\
\hline Textiles & 3 & 12 & 13 & 7 & 3 & 2 & 10 & 9 & 9 & 2 \\
\hline Paper & 0 & 3 & 13 & 4 & 2 & 0 & 2 & 5 & 8 & 3 \\
\hline Chemical & 3 & 18 & 41 & 16 & 13 & 6 & 18 & 19 & 15 & 7 \\
\hline Cement & 4 & 14 & 37 & 13 & 11 & 8 & 17 & 12 & 12 & 8 \\
\hline Iron and steel & 6 & 8 & 11 & 5 & 4 & 5 & 4 & 12 & 4 & 1 \\
\hline Metals & 2 & 5 & 18 & 8 & 7 & 0 & 5 & 5 & 12 & 4 \\
\hline General machine & 3 & 23 & 42 & 27 & 17 & 5 & 33 & 20 & 16 & 4 \\
\hline Special machine & 4 & 10 & 15 & 10 & 9 & 2 & 6 & 18 & 3 & 1 \\
\hline Transportation equ. & 12 & 17 & 19 & 8 & 2 & 2 & 11 & 12 & 7 & 22 \\
\hline Electric products & 4 & 7 & 24 & 14 & 1 & 0 & 14 & 20 & 10 & 4 \\
\hline Computer & 4 & 4 & 11 & 3 & 2 & 0 & 8 & 11 & 0 & 1 \\
\hline 12 industries' total & 48 & 130 & 263 & 121 & 77 & 31 & 150 & 146 & 98 & 60 \\
\hline
\end{tabular}


Table 3. Accumulated productivity change and structure by industry from 2005 to 2009

\begin{tabular}{lcccl}
\hline Industry name & TFP & EFFCH & TECHCH & Structure of TFP change \\
\hline Food & -0.068 & 0.155 & -0.223 & catch up \\
Textiles & 0.089 & 0.043 & 0.046 & overall improvement \\
Paper & -0.083 & 0.221 & -0.304 & catch up \\
Chemical & -0.035 & 0.037 & -0.072 & catch up \\
Cement & 0.010 & 0.078 & -0.068 & catch up \\
Iron and steel & -0.029 & -0.113 & 0.084 & frontier shift \\
Metals & 0.082 & -0.156 & 0.238 & frontier shift \\
General machine & 0.010 & -0.021 & 0.031 & frontier shift \\
Special machine & -0.025 & 0.088 & -0.113 & catch up \\
Transportation equ. & 0.024 & 0.126 & -0.102 & catch up \\
Electric products & -0.024 & 0.048 & -0.072 & catch up \\
Computer & 0.101 & 0.208 & -0.107 & catch up \\
\hline
\end{tabular}

Table 4. Number of technical innovators by year and firm scale

Number of firms identified as innovators

\begin{tabular}{lllll} 
Industry name & $2005-2006$ & $2006-2007$ & $2007-2008$ & $2008-2009$ \\
\hline Food & $0(0.0 \%)$ & $1(2.7 \%)$ & $3(8.1 \%)$ & $6(16.2 \%)$ \\
Textiles & $0(0.0 \%)$ & $7(20.0 \%)$ & $8(22.9 \%)$ & $5(14.3 \%)$ \\
Paper & $1(5.0 \%)$ & $5(25.0 \%)$ & $0(0.0 \%)$ & $7(35.0 \%)$ \\
Chemical & $2(2.6 \%)$ & $3(3.8 \%)$ & $1(1.3 \%)$ & $4(5.1 \%)$ \\
Cement & $0(0.0 \%)$ & $0(0.0 \%)$ & $3(4.4 \%)$ & $0(0.0 \%)$ \\
Iron and steel & $2(6.7 \%)$ & $6(20.0 \%)$ & $5(16.7 \%)$ & $6(20.0 \%)$ \\
Metals & $1(3.0 \%)$ & $4(12.1 \%)$ & $2(6.1 \%)$ & $3(9.1 \%)$ \\
General machine & $2(2.1 \%)$ & $3(3.2 \%)$ & $7(7.4 \%)$ & $4(4.2 \%)$ \\
Special machine & $2(5.1 \%)$ & $2(5.1 \%)$ & $4(10.3 \%)$ & $2(5.1 \%)$ \\
Transportation equ. & $0(0.0 \%)$ & $2(3.6 \%)$ & $4(7.1 \%)$ & $3(5.4 \%)$ \\
Electric products & $1(2.0 \%)$ & $1(2.0 \%)$ & $1(2.0 \%)$ & $0(0.0 \%)$ \\
Computer & $2(9.1 \%)$ & $0(0.0 \%)$ & $5(22.7 \%)$ & $4(18.2 \%)$ \\
\hline 12 industries total & $13(2.3 \%)$ & $34(6.0 \%)$ & $43(7.7 \%)$ & $44(7.8 \%)$
\end{tabular}

Note 1: There were no observations of large-scale firms in the paper industry in this study.

Note 2: Percentage values in parentheses show the share of firms identified as innovators in the total firm sample of each period and scale group by industry type.

Breakdown by firm scale (four time periods)

\begin{tabular}{llll}
\multicolumn{1}{c}{ Large } & \multicolumn{1}{c}{ Medium } & \multicolumn{1}{c}{ Small } & \multicolumn{1}{c}{ Tiny } \\
\hline $1(8.3 \%)$ & $3(8.3 \%)$ & $3(3.9 \%)$ & $3(12.5 \%)$ \\
$4(33.3 \%)$ & $2(4.2 \%)$ & $7(13.5 \%)$ & $7(25.0 \%)$ \\
$0($ N.A. $)$ & $3(25.0 \%)$ & $9(17.3 \%)$ & $1(6.3 \%)$ \\
$0(0.0 \%)$ & $0(0.0 \%)$ & $7(4.3 \%)$ & $3(4.7 \%)$ \\
$0(0.0 \%)$ & $0(0.0 \%)$ & $2(1.4 \%)$ & $1(1.9 \%)$ \\
$1(4.2 \%)$ & $7(21.9 \%)$ & $7(15.9 \%)$ & $4(20.0 \%)$ \\
$0(0.0 \%)$ & $1(5.0 \%)$ & $5(6.9 \%)$ & $4(12.5 \%)$ \\
$0(0.0 \%)$ & $6(6.5 \%)$ & $7(4.2 \%)$ & $3(2.8 \%)$ \\
$1(6.3 \%)$ & $1(2.5 \%)$ & $2(3.3 \%)$ & $6(15.0 \%)$ \\
$3(6.3 \%)$ & $2(2.9 \%)$ & $4(5.3 \%)$ & $0(0.0 \%)$ \\
$0(0.0 \%)$ & $1(3.6 \%)$ & $1(1.0 \%)$ & $1(1.8 \%)$ \\
$1(6.3 \%)$ & $1(6.3 \%)$ & $9(20.5 \%)$ & $0(0.0 \%)$ \\
\hline $11(5.7 \%)$ & $27(5.2 \%)$ & $63(6.0 \%)$ & $33(6.8 \%)$ \\
\hline
\end{tabular}


Table 5 Number of technical innovators by location (four periods)

\begin{tabular}{lllllll}
\hline & \multicolumn{5}{c}{ Number of firms identified as innovators (breakdown by province) } \\
Industry name & Jiangsu & Shandong & Shanxi & Hebei & Jilin & Sichuan \\
\hline Food & $2(8.3 \%)$ & $0(0.0 \%)$ & $6(6.8 \%)$ & $0(0.0 \%)$ & $0(0.0 \%)$ & $2(16.7 \%)$ \\
Textiles & $3(25.0 \%)$ & $0(0.0 \%)$ & $10(25.0 \%)$ & $3(8.3 \%)$ & $3(8.3 \%)$ & $1(12.5 \%)$ \\
Paper & $0(0.0 \%)$ & 0 (N.A.) & $2(25.0 \%)$ & $5(25.0 \%)$ & $6(18.8 \%)$ & $0(0.0 \%)$ \\
Chemical & $0(0.0 \%)$ & $0(0.0 \%)$ & $3(4.2 \%)$ & $3(3.9 \%)$ & $2(3.3 \%)$ & $2(7.1 \%)$ \\
Cement & $0(0.0 \%)$ & $0(0.0 \%)$ & $2(2.9 \%)$ & $0(0.0 \%)$ & $1(2.1 \%)$ & $0(0.0 \%)$ \\
Iron and steel & $7(43.8 \%)$ & $2(10.0 \%)$ & $3(18.8 \%)$ & $6(12.5 \%)$ & $1(6.3 \%)$ & $0(0.0 \%)$ \\
Metals & $3(10.7 \%)$ & 0 (N.A.) & $2(10.0 \%)$ & $1(5.0 \%)$ & $4(8.3 \%)$ & $0(0.0 \%)$ \\
General machine & $1(1.5 \%)$ & $0(0.0 \%)$ & $8(6.1 \%)$ & $5(6.3 \%)$ & $2(3.1 \%)$ & $0(0.0 \%)$ \\
Special machine & $0(0.0 \%)$ & $0(0.0 \%)$ & $4(16.7 \%)$ & $3(4.2 \%)$ & $3(25.0 \%)$ & $0(0.0 \%)$ \\
Transportation equ. & $0(0.0 \%)$ & $0(0.0 \%)$ & $5(11.4 \%)$ & $4(8.3 \%)$ & $0(0.0 \%)$ & $0(0.0 \%)$ \\
Electric products & $0(0.0 \%)$ & 0 (N.A.) & $1(1.8 \%)$ & $1(1.3 \%)$ & $0(0.0 \%)$ & $1(6.3 \%)$ \\
Computer & $0(0.0 \%)$ & 0 (N.A.) & $5(15.6 \%)$ & $6(13.6 \%)$ & $0(\mathrm{~N} . \mathrm{A})$. & $0(0.0 \%)$ \\
\hline 12 industries' total & $16(5.2 \%)$ & $2(1.6 \%)$ & $51(8.5 \%)$ & $37(6.3 \%)$ & $22(5.6 \%)$ & $6(2.5 \%)$ \\
\hline
\end{tabular}

Note 1: There were no observations for the paper, metal, electric products, and computer industries in

Shandong Province or for the computer industry in Jilin Province.

Note 2: Percentage values in parentheses show the share of firms identified as innovators in the total firm sample of each provincial group by industry type.

Table 6 Corporate performance identification matrix

\begin{tabular}{|c|c|c|c|c|}
\hline & $\begin{array}{c}\triangle \text { TFPjoint }>0 \\
\triangle \text { TFPmarket }>0\end{array}$ & $\begin{array}{l}\triangle \text { TFPjoint }>0 \\
\triangle \text { TFPmarket }<0\end{array}$ & $\begin{array}{c}\triangle \text { TFPjoint }<0 \\
\triangle \text { TFPmarket }>0\end{array}$ & $\begin{array}{c}\triangle \text { TFPjoint }<0 \\
\triangle \text { TFPmarket }<0\end{array}$ \\
\hline $\begin{array}{l}\triangle \text { Sale }>0 \\
\triangle \mathrm{CO}_{2}>0\end{array}$ & $\begin{array}{l}\text { Type } 1 \text { [176 firms }(31.3 \%)] \\
\text { - Production scale } \\
\text { expansion } \\
\text { - Economic performance } \\
\text { improvement }\end{array}$ & $\begin{array}{l}\text { Type } 5 \text { [48 firms }(8.5 \%)] \\
\text { - Production scale expansion } \\
\text { - Production input increasing }\end{array}$ & $\begin{array}{l}\text { Type } 9[21 \text { firms }(3.7 \%)] \\
\text { - Production scale } \\
\text { expansion } \\
-\mathrm{CO}_{2} \text { emissions } \\
\text { increasing }\end{array}$ & $\begin{array}{l}\text { Type } 13 \text { [112 firms }(19.9 \%)] \\
\text { - Production scale expansion } \\
\text { - Economic performance } \\
\text { worse }\end{array}$ \\
\hline $\begin{array}{l}\triangle \text { Sale }>0 \\
\triangle \mathrm{CO}_{2}<0\end{array}$ & $\begin{array}{l}\text { Type } 2 \text { [46 firms }(8.2 \%)] \\
-\mathrm{CO}_{2} \text { emissions reduction } \\
\text { without sacrificing } \\
\text { economic performance }\end{array}$ & $\begin{array}{l}\text { Type } 6 \text { [22 firms }(3.9 \%)] \\
-\mathrm{CO}_{2} \text { emissions reduction } \\
\text { with sacrificing economic } \\
\text { performance by production } \\
\text { input increased. }\end{array}$ & $\begin{array}{l}\text { Type } 10 \text { [1 firms }(0.2 \%)] \\
\text { Not available for } \\
\text { identification }\end{array}$ & $\begin{array}{l}\text { Type } 14 \text { [12 firms }(2.1 \%)] \\
\text { - Production input increasing }\end{array}$ \\
\hline $\begin{array}{l}\triangle \text { Sale }<0 \\
\triangle \mathrm{CO}_{2}>0\end{array}$ & $\begin{array}{l}\text { Type } 3 \text { [3 firms }(0.5 \%)] \\
\text { - Production input saving }\end{array}$ & $\begin{array}{l}\text { Type } 7[0 \text { firms }(0.0 \%)] \\
\text { Not available for } \\
\text { identification }\end{array}$ & $\begin{array}{l}\text { Type } 11 \text { [1 firms }(0.2 \%)] \\
\text { Product design was shifted } \\
\text { to high energy intensity } \\
\text { goods. }\end{array}$ & $\begin{array}{l}\text { Type } 15 \text { [48 firms }(8.5 \%)] \\
\text { Product design was shifted to } \\
\text { high energy intensity goods. }\end{array}$ \\
\hline $\begin{array}{l}\triangle \text { Sale }<0 \\
\triangle \mathrm{CO}_{2}<0\end{array}$ & $\begin{array}{l}\text { Type } 4 \text { [6 firms }(1.1 \%)] \\
-\mathrm{CO}_{2} \text { emissions reduction } \\
\text { without sacrificing } \\
\text { economic performance } \\
\text { (Achieved by production } \\
\text { input savings) }\end{array}$ & $\begin{array}{l}\text { Type } 8 \text { [11 firms }(2.0 \%)] \\
-\mathrm{CO}_{2} \text { emissions reduction } \\
\text { sacrificing economic } \\
\text { performance by scaling down } \\
\text { production }\end{array}$ & $\begin{array}{l}\text { Type } 12 \text { [2 firms }(0.4 \%)] \\
\text { - Production scale down } \\
\text { - Production input savings }\end{array}$ & $\begin{array}{l}\text { Type } 16 \text { [53 firms }(9.4 \%)] \\
\text { - Production scale down } \\
\text { - Economic performance } \\
\text { worse }\end{array}$ \\
\hline
\end{tabular}

Note: Percentage values in parentheses show the share of firms identified as each type in the overall number of samples (562 firms). 
Table 7 Corporate performance by industry type

\begin{tabular}{llll|lll}
\hline \multirow{2}{*}{ Industry name } & \multicolumn{3}{c}{ Improved group } & \multicolumn{3}{c}{ Deteriorated group } \\
\cline { 2 - 7 } & Type 1 & Type 2 & Type 5 & Type 13 & Type 15 & Type 16 \\
\hline Food & $11(29.7 \%)$ & $5(13.5 \%)$ & $0(0.0 \%)$ & $10(27.0 \%)$ & $3(8.1 \%)$ & $6(16.2 \%)$ \\
Textiles & $13(37.1 \%)$ & $2(5.7 \%)$ & $2(5.7 \%)$ & $5(14.3 \%)$ & $2(5.7 \%)$ & $5(14.3 \%)$ \\
Paper & $3(15.0 \%)$ & $1(5.0 \%)$ & $6(30.0 \%)$ & $4(20.0 \%)$ & $1(5.0 \%)$ & $4(20.0 \%)$ \\
Chemical & $21(26.9 \%)$ & $10(12.8 \%)$ & $2(2.6 \%)$ & $9(11.5 \%)$ & $11(14.1 \%)$ & $8(10.3 \%)$ \\
Cement & $16(23.5 \%)$ & $9(13.2 \%)$ & $5(7.4 \%)$ & $12(17.6 \%)$ & $1(1.5 \%)$ & $7(10.3 \%)$ \\
Iron and steel & $4(13.3 \%)$ & $5(16.7 \%)$ & $2(6.7 \%)$ & $9(30.0 \%)$ & $2(6.7 \%)$ & $4(13.3 \%)$ \\
Metals & $13(39.4 \%)$ & $3(9.1 \%)$ & $2(6.1 \%)$ & $9(27.3 \%)$ & $4(12.1 \%)$ & $1(3.0 \%)$ \\
General machine & $35(36.8 \%)$ & $5(5.3 \%)$ & $14(14.7 \%)$ & $25(26.3 \%)$ & $4(4.2 \%)$ & $6(6.3 \%)$ \\
Special machine & $14(35.9 \%)$ & $1(2.6 \%)$ & $3(7.7 \%)$ & $7(17.9 \%)$ & $9(23.1 \%)$ & $2(5.1 \%)$ \\
Transportation equ. & $24(42.9 \%)$ & $2(3.6 \%)$ & $4(7.1 \%)$ & $12(21.4 \%)$ & $5(8.9 \%)$ & $3(5.4 \%)$ \\
Electric products & $13(26.5 \%)$ & $1(2.0 \%)$ & $5(10.2 \%)$ & $8(16.3 \%)$ & $5(10.2 \%)$ & $5(10.2 \%)$ \\
Computer & $9(40.9 \%)$ & $2(9.1 \%)$ & $3(13.6 \%)$ & $2(9.1 \%)$ & $1(4.5 \%)$ & $2(9.1 \%)$ \\
\hline
\end{tabular}

Note: Percentage values in parentheses show the share of firms identified as each type in each group.

Table 8 Corporate performance by scale and location

\begin{tabular}{cllll|lll}
\hline & \multicolumn{3}{c}{ Improved group } & \multicolumn{3}{c}{ Deteriorated group } \\
\cline { 3 - 8 } & & Type 1 & Type 2 & Type 5 & Type 13 & Type 15 & Type 16 \\
\hline \multirow{2}{*}{$\begin{array}{c}\text { Firm } \\
\text { scale }\end{array}$} & Medium & $46(25.0 \%)$ & $2(4.2 \%)$ & $7(14.6 \%)$ & $7(14.6 \%)$ & $8(16.7 \%)$ & $5(10.4 \%)$ \\
& Small & $75(28.5 \%)$ & $27(10.3 \%)$ & $17(6.5 \%)$ & $60(22.8 \%)$ & $17(6.5 \%)$ & $27(10.3 \%)$ \\
& Tiny & $43(35.5 \%)$ & $9(7.4 \%)$ & $8(6.6 \%)$ & $24(19.8 \%)$ & $13(10.7 \%)$ & $8(6.6 \%)$ \\
\hline \multirow{2}{*}{$\begin{array}{c}\text { Location } \\
\text { (province) }\end{array}$} & Jiangsu & $39(50.6 \%)$ & $6(7.8 \%)$ & $6(7.8 \%)$ & $10(13.0 \%)$ & $5(6.5 \%)$ & $4(5.2 \%)$ \\
& Shandong & $5(16.1 \%)$ & $2(6.5 \%)$ & $3(9.7 \%)$ & $6(19.4 \%)$ & $2(6.5 \%)$ & $6(19.4 \%)$ \\
& Shanxi & $35(23.3 \%)$ & $9(6.0 \%)$ & $10(6.7 \%)$ & $48(32.0 \%)$ & $12(8.0 \%)$ & $15(10.0 \%)$ \\
& Jilin & $39(26.7 \%)$ & $16(11.0 \%)$ & $19(13.0 \%)$ & $23(15.8 \%)$ & $13(8.9 \%)$ & $16(11.0 \%)$ \\
& Sichuan & $30(30.6 \%)$ & $6(6.1 \%)$ & $8(8.2 \%)$ & $16(16.3 \%)$ & $11(11.2 \%)$ & $10(10.2 \%)$ \\
\hline
\end{tabular}

Note: Percentage values in parentheses show the share of firms identified as each type in each group. 